\title{
Evaluation of the safety of intracameral trypan blue injection on corneal tissue using oxidative stress parameters and apoptotic activity: an experimental study
}

\author{
Avaliação da segurança de injeção de azul de tripan intracameral no tecido da córnea utilizando \\ parâmetros de estresse oxidativo e atividade apoptótica: um estudo experimental
}

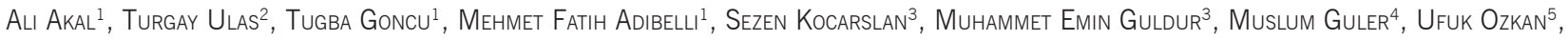
Mehmet Dusunur ${ }^{1}$, Tuncer Demir ${ }^{6}$

\begin{abstract}
Purpose: The present experimental study aimed to investigate the effects of intracameral trypan blue (TB) on oxidative stress parameters and apoptosis in corneal tissue.

Methods: Thirty rats were randomly assigned to three groups of 10 rats each: the sham group (Group 1); control group (Group 2); and treatment group (Group 3). The control group was administered $0.01 \mathrm{cc}$ of balanced salt solution. The treatment group was administered $0.006 \mathrm{mg} / 0.01 \mathrm{cc}$ of TB. The total antioxidant status (TAS) and total oxidant status (TOS) in corneal tissue and blood were measured and the oxidative stress index (OSI) was calculated. Finally, corneal tissue histopathology was evaluated using staining for caspase-3 and -8 , and apoptotic activity was examined. Results: The TAS, TOS and OSI levels in the blood samples were not significantly different ( $p>0.05$ for all). Compared with the sham and control groups, the TOS and OSI levels in corneal tissue were significantly different in the treatment group $(p<0.05$ for all). No significant difference was observed between the sham group and the control group $(p>0.05)$. Immunohistochemical staining for caspase-3 and caspase-8 demonstrated higher apoptotic activity in the TB group than in the sham and control groups.

Conclusion: The present study showed that intracameral TB injection is safe systematically but may be toxic to corneal tissue, as demonstrated using oxidative stress parameters and histopathological evaluation.
\end{abstract}

Keywords: Trypan blue/administration \& dosage; Injections; Intraocular; Cornea; Oxidative stress; Apoptosis; Animals; Rats

\section{RESUMO}

Objetivo: Este estudo experimental tem como objetivo investigar os efeitos do azul de tripan intracameral (TB) sobre parâmetros de estresse oxidativo e apoptose no tecido da córnea.

Métodos: Trinta ratos foram divididos aleatoriamente em três grupos de 10 animais cada: grupo simulação (Grupo 1); grupo controle (Grupo 2); e grupo tratamento (Grupo 3). No grupo controle foi administrado 0,01 cc de solução salina balanceada (BSS). No grupo tratamento foi administrado $0,006 \mathrm{mg} / 0,01 \mathrm{~cm}$ de TB. O estado antioxidante total (TAS) e estado oxidante total (TOS) no tecido da córnea e sangue foram medidos e o índice de estresse oxidativo (OSI) foi calculado. Finalmente, histopatologia do tecido da córnea foi avaliada por meio da coloração para caspase-3 e -8; atividade apoptótica também foi examinada.

Resultados: Os niveis de TAS, TOS e OSI das amostras de sangue não foram significativamente diferentes ( $p>0,05$ para todos). Em comparação com os grupos simulação e controle, os níveis de TOS e OSI no tecido da córnea foram significativamente diferentes no grupo tratamento ( $p<0,05$ para todos). Não houve diferença significativa entre $O$ grupo simulção e o grupo controle $(p>0,05)$. A coloração imuno-histoquímica com a caspase-3 e caspase-8 demonstrou maior atividade apoptótica no grupo tratamento do que nos grupos controle e simulação.

Conclusão: Este estudo mostrou que a injeção intracameral TB é segura sistematicamente, mas pode ser tóxica ao tecido da córnea, como demonstrado através de parâmetros de estresse oxidativo e avaliação histopatológica.

Descritores: Azul tripano/administração \& dosagem; Injeções intraoculares; Córnea; Estresse oxidativo; Apoptose; Animais; Ratos

\section{INTRODUCTION}

Trypan blue (TB) is used to facilitate the creation of a continuous curvilinear capsulorhexis during cataract surgery ${ }^{(1,2)}$. Several methods have been used to assess the toxic effects of TB on corneal cells: the concentration-related effect of TB on corneal cell viability; the effects of duration of exposure to TB on cell survival; the effect of the vehicle on the degree of TB toxicity; and the damage caused by (experimental) manipulation of cells or endothelia ${ }^{(3)}$.

Several experimental and clinical studies have tested the cytotoxicity of TB on various ocular anterior segment structures during cataract surgery, and all have demonstrated good biocompatibility for conventional intracameral application of TB $0.1 \%$. However, in vitro studies have demonstrated toxicity of TB to corneal endothelium and corneal fibroblasts at higher concentrations and longer exposure times ${ }^{(4-7)}$. Briefly, at commonly used concentrations, both during cataract surgery and in corneal tissue banks, TB is harmless to corneal cells. However, at higher concentrations or longer exposures, extreme caution is warranted.

Oxidative stress is believed to be a central mechanism of the cellular damage affecting all organs and tissues. Oxygen-derived free radicals appear to be responsible for injury to various organs, and apoptosis mediated by oxidative stress is well established ${ }^{(8-11)}$. Considering the 
controversial safety results of TB on corneal tissue mentioned above, the current study aimed to further investigate the possible toxic effects of TB using oxidative stress parameters and the degree of apoptosis in corneal tissue.

\section{METHODS}

\section{Animals AND EXPERImental Groups}

Thirty adult male Wistar Albino rats, aged 4-8 weeks and weighing 180-200 g each, were used. Animals were housed under continuous observation in appropriate cages under ambient temperature $\left(21 \pm 2^{\circ} \mathrm{C}\right)$ and humidity $(60 \% \pm 5 \%)$ with a 12 -h light:dark cycle. The animals were housed five per cage and fed a commercial standard diet with water ad libitum. All experiments in the present study were performed in accordance with the "Principles of Laboratory Animal Care" and were approved by the Ethical Committee on Human and Animal Research at Harran University, Sanliurfa, Turkey.

Rats were randomly assigned to three groups of 10 rats each as follows: the sham group (Group 1) ( $n=10)$; the control group (Group 2) $(n=10)$, which was administered $0.01 \mathrm{cc}$ balanced sterile salt solution (BSS); and the treatment group (Group 3) $(n=10)$, which was administered $0.006 \mathrm{mg} / 0.01 \mathrm{cc}$ TB.

The total antioxidant status (TAS) and total oxidant status (TOS) were measured in corneal tissue and blood, and the oxidative stress index (OSI) was calculated. Corneal tissue histopathology was evaluated using caspase- 3 and caspase- 8 staining, and apoptotic activity was assessed.

\section{SURGICAL PROCEDURES AND TISSUE PREPARATION Intracameral injection technique}

Before the intracameral injection, the rats were aseptically anesthetized with an intramuscular injection of $50 \mathrm{mg} / \mathrm{kg}$ ketamine (Ketalar; Parke Davis, Eczacibasi, Istanbul, Turkey) and $10 \mathrm{mg} / \mathrm{kg}$ xylazine (Rompun; Bayer AG, Leverkusen, Germany). Topical anesthetic drops (0.5\% proparacaine) were applied to the rats' eyes 10 min before injection. The globe was then detached from the edge of the limb using horizontal angled conjunctival forceps with teeth; anterior chamber injections, tangential to the limbus, were then administered at 3 o'clock using an insulin syringe $[0.30 \times 8 \mathrm{~mm}$ (30-G x 5/16") (Ayset Medical Products Industry Co., Adana, Turkey)] under guidance using a YZ20T9 microscope (Nanjing, Redsun Optical Co., Ltd. Jiangsu, China). Group 1 received no injection; Group 2 received intracameral BSS (0.01 cc) [Industria Farmaceutica Galenica Senese Materino d'Arbia (SI), Italy]; and Group 3 received intracameral TB (0.006 mg/0.01 cc) (Bio-Blue, Biotech Ophthalmics Pvt. Ltd, Gujarat, India). After 7 days, two rats in Group 2 and one rat in Group 3 had died.

After 7 days, rats were again anesthetized before enucleation. To reach the back of the globe, pressure was applied to the edge of the limb using conjunctival forceps and enucleation was performed using corneoscleral scissors. Following enucleation, the bulbus oculi was removed, after which all animals were euthanized by exsanguination. Round corneal specimens were removed via a limbal incision using a $15^{\circ}$ corneal blade; the histopathological specimens were placed in $10 \%$ formaldehyde and the biochemical specimens were placed into dry boxes. Last, a 3-cm midline abdominal incision was made and 1.5 cc of blood was drawn from the inferior vena cava. The tissue and blood samples were stored at $-70^{\circ} \mathrm{C}$ until measurement of TAS and TOS activity.

Repeatability of the experimental results: With regard to the repeatability of this experimental result (i.e., whether it is sufficiently repeatable in different trials), the experimental protocol does not involve any different techniques compared with previously published studies, which will help to improve the stability and repeatability of the experimental results.

\section{CAspase-3 and -8 staining}

The samples were fixed with 10\% formaldehyde and $4 \mu \mathrm{m}$ thick specimens obtained from paraffin blocks were stained using a standard streptavidin-biotin immunoperoxidase method with anti-caspase-3 (cleaved) (Clone: N/A, Catalog No: PP 229 AA, Biocare Medical) and -caspase-8 antibodies (Clone: C502S, Catalog No: GTX59555, Gene Tex). Tonsillar tissue was used as a positive control, and all specimens were evaluated using light microscopy (Olympus BX51TF, Olympus Corporation, Tokyo, Japan). Also, immunohistochemical staining was evaluated semi-quantitatively using a scale from 0 to 3 , on which negative staining was rated 0 , weak staining was rated 1 , moderate staining was rated 2 and intense staining was rated 3 .

\section{TAS}

The TAS of supernatant fractions was determined using a novel automated measurement method developed by Erel $^{(12)}$. This method produces the hydroxyl radical, the most potent biological radical. In the assay, ferrous ion solution, present in Reagent 1, is mixed with hydrogen peroxide, present in Reagent 2. The resulting radicals, such as a brown-colored dianisidinyl radical cation produced by the hydroxyl radical, are very potent. Using this method, the anti-oxidative effect of the sample against the potent free radical reactions, which are initiated by the produced hydroxyl radical, is measured. The assay yields precision values $<3 \%$. The results are expressed as nmol Trolox equivalents/mg protein.

\section{TOS}

The TOS of supernatant fractions was determined using a novel automated measurement method developed by Erel(13). The oxidants in the sample oxidize the ferrous ion-o-dianisidine complex to a ferric ion. The oxidation reaction is enhanced by glycerol in the reaction medium. The ferric ion creates a colored complex with xylenol orange in an acidic medium. The color intensity can be measured spectrophotometrically and is related to the total amount of oxidant molecules present in the sample. The assay is calibrated using hydrogen peroxide, and the results are expressed in terms of nmol $\mathrm{H}_{2} \mathrm{O}_{2}$ equivalents/mg protein.

\section{OSI}

The OSI was defined as the ratio of TOS to TAS levels. For calculations, TAS units were converted to $\mathrm{mmol} / \mathrm{L}$, and the OSI was calculated according to the following formula: OSI (arbitrary units) =TOS ( $\mu \mathrm{mol} \mathrm{H}_{2} \mathrm{O}_{2}$ equivalents/L)/TAS (mmol Trolox equivalents/L) ${ }^{(12,13)}$.

\section{Statistical analysis}

All statistical analyses were performed using SPSS for Windows software, version 17.0 (SPSS, Chicago, IL, USA), and non-parametric independent group comparisons were performed. Data were expressed as medians, minimums and maximums. The Kruskal-Wallis was used for multiple comparisons between groups and the Mann-Whitney test was used if statistical significance was found. A two-sided $p$ value $<0.05$ was considered to indicate statistical significance.

\section{RESULTS}

The TAS, TOS and OSI levels of the blood samples and corneal tissues are presented in tables 1 and 2. The TAS, TOS and OSI levels in the blood samples were not significantly different among the groups ( $p>0.05$ for all). The OSI levels in corneal tissue were significantly different in the TB group compared with the sham and control groups $(p<0.05$ for all); however, no significant difference was found between the control and sham groups ( $p>0.05$ for all). Additionally, immunohistochemical staining for caspase- 3 and -8 showed higher apoptotic activity in the TB group than in the sham and control groups (Tables 3 and 4; Figures 1 and 2). 
EVAluation of THE SAFETy OF INTRACAMERAL TRYPAN BLUE INJECTION ON CORNEAL TISSUE USING OXIDATIVE STRESS PARAMETERS AND APOPTOTIC ACTIVITY: AN EXPERIMENTAL STUDY

Table 1. Biochemical oxidative stress parameters

\begin{tabular}{|c|c|c|c|c|}
\hline & Sham group $(n=10)$ & Control group $(n=8)$ & Trypan blue group $(n=9)$ & p-value \\
\hline TAS (mmol Trolox equivalents/L) & $1.00(0.90,1.13)$ & $1.00(0.90,1.48)$ & $1.00(0.91,1.18)$ & 0.890 \\
\hline $\mathrm{TOS}\left(\mu \mathrm{mol} \mathrm{H}_{2} \mathrm{O}_{2}\right.$ equivalents/L) & $28.65(16.20,53.12)$ & $39.15(15.21,69.42)$ & $22.13(15.21,70.34)$ & 0.112 \\
\hline OSI (arbitrary units) & $2.85(1.79,6.10)$ & $4.29(3.00,6.10)$ & $3.24(2.11,5.96)$ & 0.109 \\
\hline
\end{tabular}

The variables expressed as median (minimum, maximum). The Kruskal-Wallis test was used; TAS= total antioxidant status; TOS= total oxidant status; OSI= oxidative stress index.

Table 2. Corneal tissue oxidative stress parameters

\begin{tabular}{|c|c|c|c|c|}
\hline & Sham group $(n=10)$ & Control group $(n=8)$ & Trypan blue group $(n=9)$ & p-value \\
\hline TAS (mmol Trolox equivalents/L) & $0.28(0.14,0.44)$ & $0.52(0.17,0.97)$ & $0.25(0.16,0.29)$ & 0.068 \\
\hline $\mathrm{TOS}\left(\mu \mathrm{mol} \mathrm{H}_{2} \mathrm{O}_{2}\right.$ equivalents/L) & $5.13(2.67,9.51)$ & $4.18(1.38,8.25)$ & $4.01(1.98,4.73)$ & 0.125 \\
\hline OSI (arbitrary units) & $1.27(1.01,1.71)$ & $1.35(1.02,1.96)$ & $1.82(1.48,2.04)^{*, \pm}$ & 0.002 \\
\hline
\end{tabular}

The variables expressed as median (minimum, maximum). Kruskal-Wallis and Mann-Whitney $\mathrm{U}$ tests were used; TAS= total antioxidant status; TOS= total oxidant status; OSI= oxidative

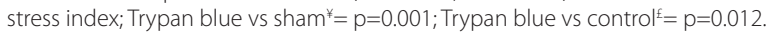

Table 3. Immunohistochemical staining for caspase-3

\begin{tabular}{lccccc}
\hline & $\mathbf{0}$ & $\mathbf{+}$ & $\mathbf{+ +}$ & $\mathbf{+ + +}$ & Total \\
\hline Sham group & 9 & 1 & - & - & 10 \\
Control group & 7 & 1 & - & - & 8 \\
Trypan blue group & 4 & 4 & 1 & - & 9 \\
\hline
\end{tabular}

\section{Table 4. Immunohistochemical staining for caspase-8}

\begin{tabular}{llllcc}
\hline & $\mathbf{0}$ & $\mathbf{+}$ & $\mathbf{+ +}$ & $\mathbf{+ + +}$ & Total \\
\hline Sham group & 9 & 1 & - & - & 10 \\
Control group & 6 & 2 & - & - & 8 \\
Trypan blue group & 3 & 4 & 2 & - & 9 \\
\hline
\end{tabular}
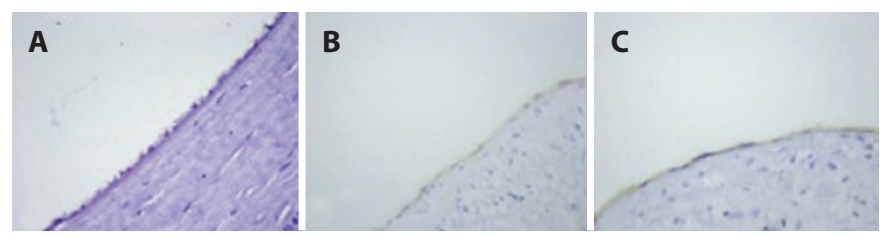

Figure 1. Immunohistochemical staining of the endothelial cells for caspase-3. Negative $(\mathrm{A})$, weak (B), and moderate (C) (caspase-3 $\times 400)$.
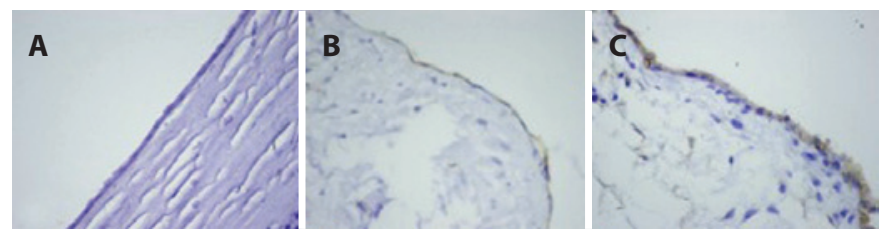

Figure 2. Immunohistochemical staining of the endothelial cells for caspase 8. Negative $(A)$, weak $(B)$, and moderate $(C)($ caspase $-8 \times 400)$.

\section{DISCUSSION}

The present study yielded intriguing results and, to our knowled$\mathrm{ge}$, is the first report of the safety of intracameral TB in corneal tissue using oxidative stress parameters and apoptotic activity. The present study showed that although intracameral TB does not exert a systemic effect, it might be locally toxic to corneal tissue.

Clinically, TB is commonly used at $0.06 \%$ or $0.10 \%$, and is instilled into the anterior chamber for 1 min, with or without air or an ophthalmic viscosurgical device, before washout ${ }^{(14)}$. Most studies investigating potential TB toxicity have examined the effects of TB on corneal cells in vitro(1,3,4,15,16). Panda et al. included 205 eyes of 205 patients that had undergone phacoemulisification of cataracts or corneal opacities ${ }^{(17)}$. The authors revealed that TB (0.06\%) dye-assisted capsulorhexis was successfully completed in all eyes and the patients were followed up at day 1 , day 7, and one and three months postoperatively. Also, some studies found good biocompatibility at incubation times of up to $15 \mathrm{~min}$ and concentrations up to $0.40 \%$, indicating that TB is safe for corneal endothelial cells $s^{(3,4,15,18-21)}$. Chung et al. also evaluated the safety of TB 1\% for assisting visualization of the anterior capsule during phacoemulsification of a mature cataract, and found it to be safe ${ }^{(22)}$. Moreover, Norn reported the perioperative use of this dye (at $0.1 \%$ ) for the staining of corneal endothelium in anterior segment surgery. No ocular complications were found during eight years of follow-up. Additionally, Melles et al. advocated the use of TB $(0.1 \mathrm{~mL}$ of a $0.06 \%$ solution) to visualize the anterior capsule in cataract surgery ${ }^{(1,15)}$.

Although the safety of TB is well established, it is not without reports of toxicity. Several animal studies have indicated that TB has teratogenic and carcinogenic potential(16,23,24). In animal studies, increasing the concentration from that used clinically $(0.006 \mathrm{mg})$ to $0.017 \%$ resulted in a $38 \%$ reduction in endothelial cell viability using generic TB and 15\% using the proprietary TB. When the concentration was increased to $0.05 \%$, viability decreased by $55 \%$ with generic TB, and by $30 \%$ with the proprietary TB. A study performed using corneal fibroblasts and endothelial cells in human donor eyes demonstrated a TB-induced dose-dependent cytotoxic effect after incubation times of up to $24 \mathrm{~h}$. High TB concentrations and long incubation times have also been shown to exhibit significant cytotoxicity in human cultured corneal endothelial cells $s^{(14,25)}$.

Given these findings, controversy exists over whether TB is safe for corneal tissue. In our study, we detected no systemic effects using oxidative stress parameters from blood samples; however, caspase-3 and -8 staining demonstrated increased apoptotic activity in the corneal tissue samples, and levels of oxidative stress markers were also increased.

\section{CONCLUSIONS}

Our evaluation showed that intracameral TB is safe systemically but may be toxic to corneal tissue, as confirmed by histopathological evaluation. However, the present study was performed in animals and future clinical studies are needed to support these findings in humans. 


\section{REFERENCES}

1. Melles GR, de Waard PW, Pameyer JH, Houdijn Beekhuis W. Trypan blue capsule staining to visualize the capsulorhexis in cataract surgery. J Cataract Refract Surg. 1999; 25(1):7-9.

2. Jacobs DS, CoxTA, Wagoner MD, Ariyasu RG, Karp CL; American Academy of Ophthalmology; Ophthalmic Technology Assessment Committee Anterior Segment Panel. Capsule staining as an adjunct to cataract surgery: a report from the American Academy of Ophthalmology. Ophthalmology. 2006;113(4):707-13.

3. van Dooren BT, Beekhuis WH, Pels E. Biocompatibility of trypan blue with human corneal cells. Arch Ophthalmol. 2004;122(5):736-42

4. van Dooren BTH, de Waard PWT, Poort-van Nouhuys H, Beekhuis WH, Melles GR. Corneal endothelial cell density after trypan blue capsule staining in cataract surgery. J Cataract Refract Surg. 2002;28(4):574-5.

5. Dada VK, Sharma N, Sudan R, Sethi H, Dada T, Pangtey MS. Anterior capsule staining for capsulorhexis in cases of white cataract: comparative clinical study. J Cataract Refract Surg. 2004;30(2):326-33.

6. Jacob S, Agarwal A, Agarwal A, Agarwal S, Chowdhary S, Chowdhary R, Bagmar AA Trypan blue as an adjunct for safe phacoemulsification in eyes with white cataract. J Cataract Refract Surg. 2002;28(10):1819-25.

7. Pohanish RP, editor. Sittig's handbook of toxic and hazardous chemical carcinogens $5^{\text {th }}$ ed. Norwich, NY: William Andrew; 2008. p.2528.

8. Ulas T, Buyukhatipoglu H, Kirhan I, Dal MS, Ulas S, Demir ME, et al. Evaluation of oxidative stress parameters and metabolic activities of nurses working day and night shifts. Rev Esc Enferm USP. 2013:47(2):471-6.

9. Yalcin S, Ulas T, Eren MA, Aydogan H, Camuzcuoglu A, Kucuk A, et al. Relationship between oxidative stress parameters and cystatin $C$ levels in patients with severe preeclampsia. Medicina (Kaunas). 2013;49(3):118-23.

10. Ma JQ, Ding J, Zhang L, Liu CM. Hepatoprotective properties of sesamin against CCl4 induced oxidative stress-mediated apoptosis in mice via JNK pathway. Food Chem Toxicol. 2014;64:41-8.

11. Tanaka Y, Komatsu T, Shigemi H, Yamauchi T, Fujii Y. BIM(EL) is a key effector molecule in oxidative stress-mediated apoptosis in acute myeloid leukemia cells when combined with arsenic trioxide and buthionine sulfoximine. BMC Cancer. 2014;14:27.

12. Erel O. A new automated colorimetric method for measuring total oxidant status. Clin Biochem. 2005;38(12):1103-11.
13. Erel $\mathrm{O}$. A novel automated method to measure total antioxidant response against potent free radical reactions. Clin Biochem. 2004;37(2):112-9.

14. Thaler S, Hofmann J, Bartz-Schmidt KU, Schuettauf F, Haritoglou C, Yoeruek E. Methyl blue and aniline blue versus patent blue and trypan blue as vital dyes in cataract surgery: capsule staining properties and cytotoxicity to human cultured corneal endothelial cells. J Cataract Refract Surg. 2011;37(6):1147-53.

15. Norn MS. Per operative trypan blue vital staining of corneal endothelium. Eight years' follow up. Acta Ophthalmol (Copenh). 1980;58(4):550-5.

16. Veckeneer M, van Overdam K, Monzer J, Kobuch K, van Marle W, Spekreijse H, van Meurs J. Ocular toxicity study of trypan blue injected into the vitreous cavity of rabbit eyes. Graefes Arch Clin Exp Ophthalmol. 2001;239(9):698-704.

17. Panda A, Krishna SN, Dada T. Outcome of phacoemulsification in eyes with cataract and cornea opacity partially obscuring the pupillary area. Nepal J Ophthalmol. 2012; 4(2):217-23.

18. Sperling S. Evaluation of the endothelium of human donor corneas by induced dilation of intercellular spaces and trypan blue. Graefes Arch Clin Exp Ophthalmol. 1986; 224(5):428-34.

19. Chang YS, Tseng SY, Tseng SH, Chen YT, Hsiao JH. Comparison of dyes for cataract surgery. Part 1: cytotoxicity to corneal endothelial cells in a rabbit model. J Cataract Refract Surg. 2005;31(4):792-8.

20. Kothari K, Jain SS, Shah NJ. Anterior capsular staining with trypan blue for capsulorhexis in mature and hypermature cataracts; a preliminary study. Indian J Ophthalmol. 2001;49(3):177-80.

21. Yoeruek E, Spitzer MS, Tatar O, Aisenbrey S, Bartz-Schmidt KU, Szurman P. Safety profile of bevacizumab on cultured human corneal cells. Cornea. 2007:26(8):977-82

22. Chung CF, Liang CC, Lai JS, Lo ES, Lam DS. Safety of trypan blue $1 \%$ and indocyanine green $0.5 \%$ in assisting visualization of anterior capsule during phacoemulsification in mature cataract. J Cataract Refract Surg. 2005;31(5):938-42.

23. Chung KT. The significance of azo-reduction in the mutagenesis and carcinogenesis of azo dyes. Mutat Res. 1983;114(3):269-81.

24. Ema M, Kanoh S. [Studies on the pharmacological bases of fetal toxicity of drugs. (II). Effect of trypan blue on the pregnant rats and their offspring]. Nihon Yakurigaku Zasshi. 1982;79(5):369-81.

25. Buzard K, Zhang JR, Thumann G, Stripecke R, Sunalp M. Two cases of toxic anterior segment syndrome from generic trypan blue. J Cataract Refract Surg. 2010;36(12):2195-9.

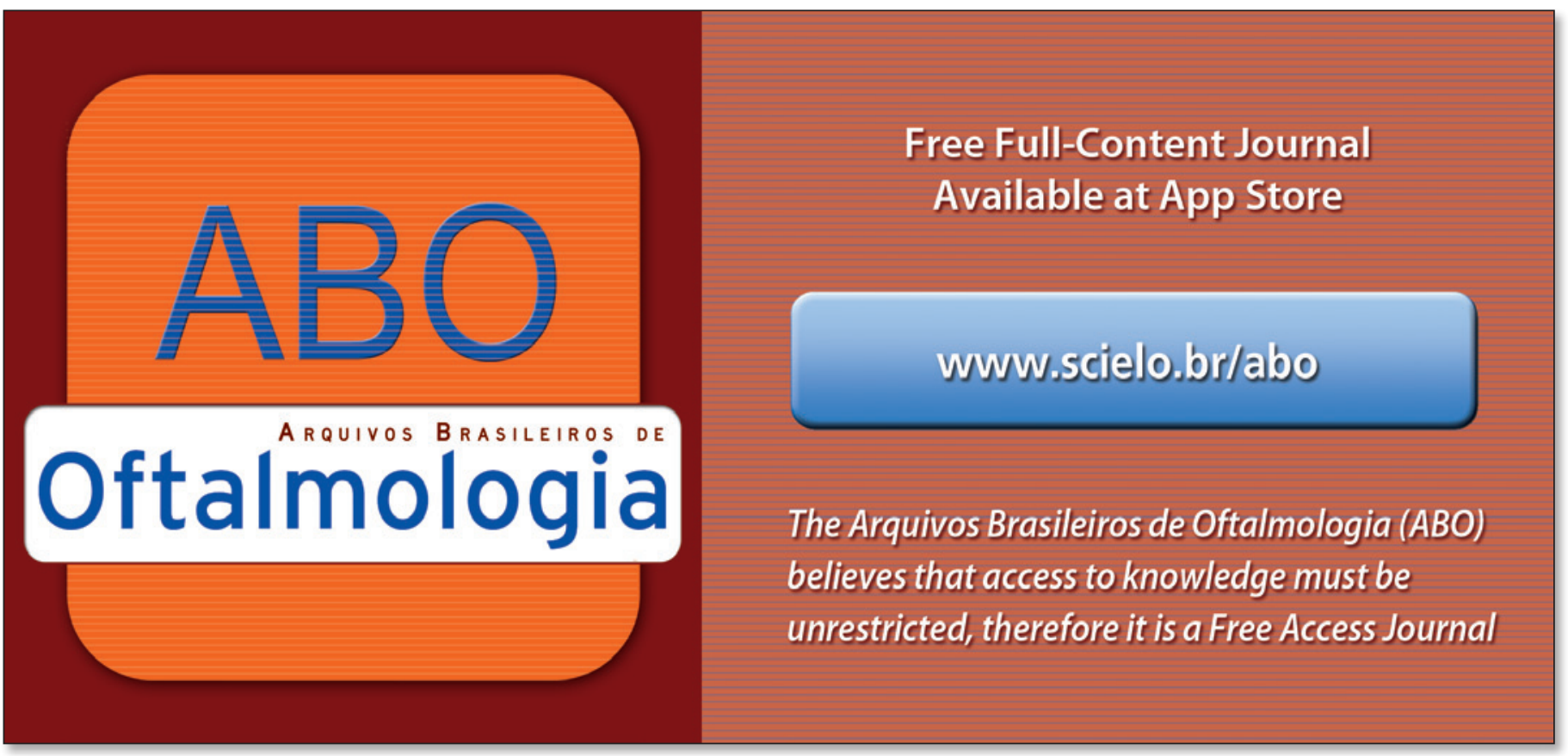

